\title{
The Impact of Audiobook on Improving Jordanian Basic Education Students' Reading Comprehension.
}

\author{
AhlamTahaSalemAl.fakara \\ A Teacher of English - Ministry of Education
}

\begin{abstract}
This study aimed at Improving Jordanian Basic Education Students' Reading Comprehension by using audiobooks. To fulfill this purpose, two instruments were constructed: a reading skills questionnaire to determine the necessary reading skills for tenth grade/ basic stage students and a pre - post reading comprehension test to assess EFL students' reading comprehension skills before and after the study intervention. The validity and reliability of the study instruments were established before their application in the study. The quasiexperimental design was adopted. The participants of the study were sixteen students selected from the tenth grade basic stage students at The Martyr Pilot Muath Al-Kasasbeh in AL-karak Directorate, Jordan. The experimental group students were taught through the proposed audiobooks activities while the control group students studied through the regular instructional activities. Results revealed that the experimental group students EFL reading skills were significantly improved. It was recommended that audiobook should be used in EFL teaching to improve speaking skills and other language skills.
\end{abstract}

Key words: reading comprehension laudiobooks

\section{Introduction}

The four skills play a vital As one growths, so does other. role at communication with others Reading improves speaking skills, also in foreign learning-teaching process. Each one of these skills is related to another skill as there is a relation between listening and writing skills as well as reading and speaking skills. Currently, it is supposed that listening and writing as well as reading and speaking skills have a common connection. and speaking skills improve reading.

Haboush (2010) defined reading as the majority of mental activities in which visible group of symbols turning into 'talk', or within the case of silent reading, into an image of speech sounds. Reading is also totally and 
comprehensively outlined it as "a visual and cognitive process to extract meaning from writing by understanding the written text, processing information, and relating it to existing experience.

Language acquisition without reading is difficult. Reading is a good way of comprehension. A good reader is able to understand sentences and structures of a written text. It appears that reading is a key factor in language learning (Mart, 2012).

Reading can play a big part in successful language learning. It can develop speaking skills. Learners through reading developed both fluency and accuracy of expression in their speaking. It is clear that speaking occupied an awfully important place in foreign language learning as speech messages are conveyed (Mart, 2012).

In spite of the importance of reading comprehension skills for EFL learners, students face a number of difficulties that include inability to process new vocabulary and concepts in a meaningful manner, less prior knowledge and skill in relevant domain and difficulty in identifying the main idea.

The present study used audiobook activities to improve reading comprehension skills for basic education students in Jordan.

\section{Review of Literature}

\section{The Reading Comprehension Skill}

Reading generally is an important academic skill in life and especially at the EFL classes' educational activities, as it is a basis of success in one's life and it's a vital skill which the learners need in their first school years.

Reading is an interactive skill in which the reader interacts with the text and employs his experience and previous knowledge to get the meaning and understand vocabulary, grammar and sentence structure encoded by the writer from the text. So reading skills and strategies should be 
given high priority and practiced consistently. Reading skills depend on the students' needs, teaching objectives, and the educational context. (Tashtoush, 2008). Nunan (2003) defines reading as " a fluent process of readers combining information from a text and their own background knowledge to build meaning and the goal of reading is comprehension "

Moreover, reading is an active process through which readers interact with text to reconstruct the message of the author. Printed symbols are signs which lead an active mind to reflect on alternatives during the process of constructing knowledge (Kelly, 2007).

As mentioned above, some define reading as understanding interpret meaning sense, some may look at reading as an interaction process between the reader and the text. Some view it as decoding decipher identify, and other use it as articulating speaking pronounce. Therefore the definition of reading depends on the texts we read and the reader's purposes from reading

In this study reading comprehension is the ability to understand the text, analyze the information and interpret correctly what the author is stating.

Reading is a flexible process, it changes for each generation of students and teachers. Nunan (2003) defines reading as " a fluent process of readers combining information from a text and their own background knowledge to build meaning and the goal of reading is comprehension "

Reading process has changed as a receptive process to an interactive one. Reading as an interaction of some processes has two categories which need obtaining a message from the text; (1) bottom-up process in which the learners gain meaning from the written material and reconstruct it. (2) Top-up process where the learners can deal with the text as a whole part to relate it to their 
experiences and knowledge (Allen, 2003).

The concept of active reading is crucial because of the complexity of the reading process.

Learners aren't just passively receive information, they also have to consciously make sense of what they are reading (Beck \&McKeown, 2006).

Moreover, reading is an active process through which readers interact with text to reconstruct the message of the author. Printed symbols are signs which lead an active mind to reflect on alternatives during the process of constructing knowledge (Kelly, 2007).The purposes of reading process are comprehension and understanding where priority should be given to meaning (Hashemi\&et. al, 2016).

To Costea (2011), it is very vital to consider the following basic components of reading process when designing it:

First,multiple readings including initial reading, re-reading, reading selective reading plural, etc.Second,meta-textual reflections that highlight certain aspects of the text as using standard, techniques of story and some intercultural issues. Third, related activities such as activity of producing text meaning as work with the whole class, work groups (monitors), work in tandems as two students, one teacher plays, and individual work , and using available documentary sources (dictionaries, encyclopedias, etc.

Reading difficulties are common and are associated with poor long-term academic achievement. Most school-age children with reading difficulties fail to catch up with their peers, and become literate, many continue to have reading difficulties and never become fluent readers. Those should receive individualized instruction to increase phonologic awareness, decoding skills, sight word vocabulary, and reading comprehension (Hamilton \&Glasoe, 2006). 
Educators and language researchers state some reasons for Failure in reading comprehension: Whittingham and et.al (2013) states that the inability to process new vocabulary and concepts in a meaningful manner, losing interest in reading,and entering a state of learned helplessness are the reasons for a poor school performance which the learners encounter in reading.

Regarding the reading text of the material, many aspects of the text might make the reading process difficult. Although the language of the text is known to be the major variable, there are other factors like aspects of text content, text type, text organization, and sentence structure (Freahat\& Al Faoury, 2015).

\section{Related Studies}

Shadi (2015) investigated the effectiveness of using Web Quests on (30) first year secondary school students' English reading and writing skills. The instruments of the study was an achievement reading and writing skills test of two sections with (11) items and an attitude questionnaire to measure the students' attitudes towards the Web Quest in acquiring English reading and writing skills. The findings were: first, there were statistically significant differences between the pre and post reading and writing skills test in favor of the treatment group. Second there was a large effect of the Web Quest program on improving the students' reading and writing skills. Third, there was an overall attitude towards the Web Quest program. The researcher recommended some recommendations for teachers, EFL textbook writers, stakeholders of TEFL and for the educational administrators.

El Dwil (2017) examined the effect of digital stories for developing reading skills of 35 EFL preparatory school pupils using a questionnaire and a prepost reading comprehension skills test. The findings indicated that using digital enhance reading 
comprehension skills among second year preparatory school pupils. The researcher recommended it is important to use digital stories in teaching the EFL language skills.

Teaching English language learners through technology explores the use of computers and technology as pedagogical tools to be selected and used in the appropriate instruction of English language by learners EFLs across all areas (Erben, Ban \& Castaneda, 2004).

Technology development has changed not only the way classroom appear, but also necessitates a change in how students in the classrooms learn. However a problem continues to exit related to teachers using technology in meaningful ways for instruction. Teacher should understand the benefit of technology in teaching and learning and find meaningful ways of technology integration in teaching (Liu, 2005).
The source of the study problem was clear through literature review.

The researcher reviewed some studies which conducted on the same variables. Some studies about using audiobooks to improve reading comprehension skills were applied on the same basic stage. Others were applied on other EFL skills, and some studies adopted the same variables of the current study.

As a result, the studies as Shadi (2015) and El Dwil (2017) were beneficial for the researcher; the instruments of the study were designed in the light of these studies foundations. They shed light on what has been investigated in the field of reading skills and technology and what has not yet investigated. These two studies are in agreement in their results with the current study.

\section{Audiobooks}

Audiobook dates back to the Victorian era where they were introduced to consumers as 
accessibility tools for the impaired. They were appeared in 1878 as talking books. Such books would be listened to where now none are read. They would preserve more than the mental emanations of the brain of the author; and, as a bequest to future generations, they would be unequaled (Camlot, 2003).

As Burkey (2012) explains, by 1948 , early commercial recordings were offered on long playing records, but by 1963 , the Philips Corporation introduced the cassette tape. The Los Angelesbased Deyan Institute of Vocal Artistry and Technology (DIVA) which opened in 2014, billing itself as the world's first school for teaching the art and technology of audiobook production (Young, 2016).

Audio recordings of texts have been in existence for nearly a century. As early as 1877 , Thomas Edison envisioned the phonograph as an oral book reading device, and his very first recording on the phonograph, a recitation of "Mary
Had a Little Lamb" might generously be considered the first children's read along (Cahill \& Moore, 2017).

\section{Advantages of using audiobooks}

Listening to audiobooks increases and enhances such literacy skills as vocabulary, fluency, and comprehension for both accomplished and struggling readers, as well as Englishlanguage learners. Audiobooks offer a unique opportunity to share stories in a way that not only increases comprehension but also heightens enjoyment. $\mathrm{He}$ has advised many parents on the benefits of audiobooks in their child's literacy development (Burkey, 2013).

Serafini (2004) offers several reasons why teachers and parents are encouraged to use audiobooks; Allow reader to know new vocabulary which become part of a child's oral and eventually written vocabularies, provide the reader with fluent reading and appropriate phrasing, intonation, and 
articulation, access to materials for readers: Experienced readers and those struggling with decoding can listen to stories well beyond their independent reading levels and comprehend more complex literature, create opportunities for readers to discuss literature through which reading comprehension is enhanced through discussion, and audiobooks provide a perfect opportunity for classes to share these stories, invite children into the world of reading and literature. One of the most important roles of classroom teachers and librarians is exposing children to quality literature and support struggling readers as developing readers listen to audiobooks and follow along with a printed version of the story, they learn to match the sounds of oral language to their written counterparts. This matching of sounds to symbols is the basis for reading instruction.

\section{Audiobook Formats}

Audiobooks have several formats such as records, cassette tapes, CDs, MP3 players, and online books, they can also be found in a variety of places online to listen to through the computer while following along with the text on the screen, or to purchase and download. They are rising in popularity due to so many people being connected to their iPods, cell phones, or MP3 players, they became the most popular collections in many libraries (Hett, 2012).

Audiobook as an Educational Tool:

Teachers should use and implement compensatory strategies to facilitate learning, avoid downgrading the intellectual skills and preserve students' self-esteem. One of the most of these recommended strategies is using a recorder and tapes (recorded by teachers, pupils and/or tapes attached to books) or synthesizers in order to read scanned texts. Another frequently issued recommendation is that an archive containing the recordings of the adopted book list and other 
culturally relevant books should be set up in every school (Milani, et. al., 2009). Teachers should use and implement compensatory strategies to facilitate learning, avoid downgrading the intellectual skills and preserve students' self-esteem. One of the most of these recommended strategies is using a recorder and tapes (recorded by teachers, pupils and/or tapes attached to books) or synthesizers in order to read scanned texts (Milani, et. al., 2009).

\section{Audiobooks in Classroom:}

Audiobooks make literature as a phenomenon to be enjoyed than a puzzle to be solved. They are a fresh chance to find way to books, and to hold onto them (Varely, 2002).

Bringing the audiobook into the classroom becomes very simple and inexpensive with the availability of iPods and similar audio devices. There are many advantages of using audiobooks as improving fluency, expand vocabulary, activate prior knowledge,

develop comprehension, and increase motivation to interact with books. Also audiobooks remove the restraints of word recognition and decoding allows a very positive focus on the meaning behind an author's words. Furthermore, they provide opportunity for many students, including those with special needs, to experience the same books as the other students. (Wolfson, 2008).

A number of studies was conducted on audiobooks to investigate their effect on EFL learners' reading skills such as Karatal (2011), Turker (2010) Monntgomry (2009), and " Whittingham and et.al (2013) that are in greement with the results of the current study.

Karatal (2011) revealed in his study entitled "The Use of Audiobooks in EFL Class to Improve Reading and Listening Skills" that audio books are helpful for improving reading comprehension and listening skills as well as reading fluency. But, 
there are some limitations. First, composing experimental and control group is not an easy task as it is difficult to assess language skills thoroughly. Second, the quality of recording might affect the contributors. Last, after the process it may not be the audio books but other factors that cause a change in language those research areas.

Turker (2010) investigated in a study entitled "The effectiveness of using audio books on the reading comprehension of selected text by university EFL students at different proficiency levels". The study showed that there is a positive effect on the ability of EFL university students to comprehend a selected text and intermediate level students gained more benefit from using audiobooks than the elementary level. The researcher recommended integrating audiobooks in the reading course of the university curriculum.

$$
\text { Another study by }
$$
Monntgomry (2009) entitled
Using Audio Books to improve reading and Academic Performance revealed that audiobooks can improve reading and academic performance for both English Learners and for native English speakers, it proved the impact of using audiobooks on academic performance and behavior of students, especially at the middle school level. The researcher recommended using audiobooks to generate renewed enthusiasm for reading by involving teachers, students, public libraries and parents in learning process to increase student reading proficiency.

Whittingham and et.al (2013), conducted a study to investigate the impact of the use of audiobooks with struggling readers in a school library audiobook club. The participants of the study were (21) students in grades 4 and 5 in a rural Elementary School Housing grades $\mathrm{K}-5$. The instruments of the study were pre- post-test, interviews and surveys, teacher questionnaires, parent 
questionnaires, and student interviews. The results of the study indicated that struggling readers' use of audiobooks had a positive impact on reading skills and attitudes toward reading. The study concluded that Teachers and school librarians should add audiobooks to the list of reading strategies used successfully with struggling readers.

The above studies showed the importance of using audiobooks, at different grade levels and with different skills. They also showed that using audiobooks could enhance EFL learners' reading skills. The results of these studies were beneficial for the current study in using audiobooks activities to enhance the students' EFL basic education students' reading skills. Additionally they are in agreement with the results of current study.

\section{The pilot study:}

A pilot study was conducted to assess the students' current level in EFL reading skills. A selected sample was taken from Al.Marj Basic school for girls in AL-Karak Directorate to check students' reading performance in the first midterm exam 2017. The sample included 30 girls. The following table shows the mean score and the percentage of reading section in the English language test.

Table (1)

The analysis of the results of the pilot study test

\begin{tabular}{|c|c|c|c|c|}
\hline Reading Skill & mean & $\begin{array}{c}\text { Std. } \\
\text { Deviation }\end{array}$ & $\begin{array}{c}\text { The } \\
\text { Highest } \\
\text { Grade }\end{array}$ & $\begin{array}{c}\text { Passing } \\
\text { Grade }\end{array}$ \\
\hline Skimming & 1.98 & 1.09 & 4 & 2 \\
\hline Scanning & 2.50 & 2.06 & 6 & 3 \\
\hline $\begin{array}{c}\text { Identifying the meaning of } \\
\text { new words }\end{array}$ & 2.97 & 1.83 & 6 & 3 \\
\hline Inference & 1.53 & 1.63 & 4 & 2 \\
\hline Total & 8.98 & 5.58 & 20 & 8 \\
\hline
\end{tabular}


It has been noticed that the level of students in reading comprehension skills is below the desired and required average. Additionally, the four sub skills of skimming, scanning, identifying new meaning of words, and inference have a statistical averages of (8.98).

\section{Statement of the Problem}

Based on the researchers experience as a teacher of EFL and on the results of the pilot study, the problem of the current study can be stated as follows: Jordanian EFL basic school students have difficulties in reading comprehension skills such as identifying the main idea of reading text, uesing the meaning of new words through the context, using headlines and supporting details to find correct information, and inferring mood and author's attitude or tone.

This study proposed the use of audiobook activities to help the students improve their reading comprehension skills.

\section{Questions of the Study:}

What is the impact of Audiobook on improving Jordanian basic education students' reading comprehension?

For research purposes, the following sub-questions were derived from the main question:
1. What is the effectiveness of the audiobook in enhancing $10^{\text {th }}$ grade basic stage students' EFL reading comprehension skills?

2. What are the characteristics of audiobook activities for developing these sub-skills?

\section{Purpose of the Study:}

The present study aims at:

1. Developing reading comprehension skills of basic stage students.

2. Measuring the effectiveness of using audiobooks activities indeveloping EFL basic stage students' reading comprehension skills.

\section{Hypotheses of the Study}

The study hypothesized that

1. There is a significant difference at 0.05 level between the mean score of the experimental group students' on the pre - post administration of the reading comprehension test in favor of the post one.

2. There is a significant difference at 0.05 level between the mean score of the control group and the experimental group on the post administration of the reading comprehension test in favor of the experimental group. 


\section{Method}

\section{Design:}

The study adopted the quaisexperimental design using one group (experimental group). Both groups(experimental and control groups) received the pre- post reading test assess the target reading skills.

\section{Participants:}

The participants was one experimental group of tenth grade students from The Martyr Pilot Muath Al-Kasasbeh Secondary School for Boys in Al-Karak Directorate, Jordan. One class will be assigned as the experimental group that will study using audiobook. Participants were divided into two groups: one control and one experimental, and each group consisted of 30 students. The experimental group students' were taught through audiobook while the control group student studied through the regular instructions and activities planned by the ministry of education in Jordan.

\section{Instruments:}

The following instruments were designed and used in:

1. A list of reading comprehension skills necessary for EFL basic stage students' for determining the reading comprehension that should be mastered by EFL basic stage students.

2. A pre- post reading comprehension skills tests for assessing the reading comprehension for $\mathrm{EFL}$ basic stage students.

\section{Results and discussions}

Results were statistically analyzed in terms of the study hypotheses. They were discussed in the light of the theoretical background and related studies. Results were reported as follows:

\section{Testing the first hypothesis:}

The first hypothesis stated that there is a significant difference at 0.05 level between the mean score of the experimental group students on the pre - post administration of the reading comprehension test in favor of the post one ". In order to validate this hypothesis, the researcher used ttest 


\section{Table (2)}

$T$ - test of the experimental group on the pre -post administration of the EFL reading comprehension test.

\begin{tabular}{|c|c|c|c|c|c|c|c|c|c|c|}
\hline $\begin{array}{l}\text { Main } \\
\text { Skills }\end{array}$ & Sub Skills & Test & $\mathrm{N}$ & Mean & $\begin{array}{l}\text { Mean paired } \\
\text { differences }\end{array}$ & SD & $\begin{array}{c}\text { SD } \\
\text { paired } \\
\text { differences }\end{array}$ & $\mathrm{df}$ & $\mathrm{t}$ & Sig \\
\hline \multirow{4}{*}{ 先 } & \multirow{2}{*}{ first skill } & Pre-test & 30 & 0.92 & \multirow{2}{*}{1.29} & 0.981 & \multirow{2}{*}{1.160} & \multirow{2}{*}{29} & \multirow{2}{*}{6.100} & \multirow[t]{2}{*}{0.01} \\
\hline & & Post- test & 30 & 2.21 & & 0.537 & & & & \\
\hline & \multirow{2}{*}{ Second skill } & Pre-test & 30 & 0.54 & \multirow{2}{*}{1.75} & 0.630 & \multirow{2}{*}{0.843} & \multirow{2}{*}{29} & \multirow{2}{*}{11.366} & \multirow[t]{2}{*}{0.01} \\
\hline & & Post- test & 30 & 2.29 & & 0.474 & & & & \\
\hline \multirow{8}{*}{ 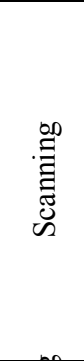 } & \multirow{2}{*}{ Third skill } & Pre-test & 30 & 0.75 & \multirow{2}{*}{1.71} & 0.905 & \multirow{2}{*}{1.011} & \multirow{2}{*}{29} & \multirow{2}{*}{9.256} & \multirow[t]{2}{*}{0.01} \\
\hline & & Post- test & 30 & 2.46 & & 0.228 & & & & \\
\hline & \multirow{2}{*}{ Fourth skill } & Pre-test & 30 & 0.67 & \multirow{2}{*}{1.67} & 0.786 & \multirow{2}{*}{0.826} & \multirow{2}{*}{29} & \multirow{2}{*}{11.050} & \multirow[t]{2}{*}{0.01} \\
\hline & & Post- test & 30 & 2.33 & & 0.432 & & & & \\
\hline & \multirow{2}{*}{ Fifth skill } & Pre-test & 30 & 0.63 & \multirow{2}{*}{1.75} & 0.787 & \multirow{2}{*}{0.843} & \multirow{2}{*}{29} & \multirow{2}{*}{11.366} & \multirow[t]{2}{*}{0.01} \\
\hline & & Post- test & 30 & 2.38 & & 0.381 & & & & \\
\hline & \multirow{2}{*}{ sixth skill } & Pre-test & 30 & 0.29 & \multirow{2}{*}{2.08} & 0.538 & 0826 & 20 & 13813 & 0.01 \\
\hline & & Post- test & 30 & 2.38 & & 0.381 & & & 13.813 & \\
\hline 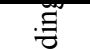 & coventb ckil & Pre-test & 30 & 0.29 & 13 & 0.710 & 0745 & 20 & 15624 & 0.01 \\
\hline 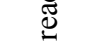 & seventil skiाI & Post- test & 30 & 2.42 & 2.13 & 0.317 & 0.145 & $29 \mid$ & 15.024 & \\
\hline త్లే & Fiohth skill & Pre-test & 30 & 0.29 & 208 & 0.630 & 0683 & 20 & 16600 & 0.01 \\
\hline & E1ghth skill & Post- test & 30 & 2.38 & 2.08 & 0.381 & 0.083 & $29 \mid$ & 10.099 & \\
\hline & skills & Pre-test & 30 & 4.38 & 1446 & 2.429 & 2599 & 29 & 30470 & 001 \\
\hline & II SKIIIS & Post- test & 30 & 18.83 & & 1.181 & 2.399 & & & \\
\hline
\end{tabular}

Comparing the mean scores in the pre- post administration of the reading comprehension test reveals that the experimental group students' mean score in the overall pre reading comprehension test is (4.38), whereas their mean score in the overall post reading comprehension test is (18.83). These values indicated the significant difference between the mean scores before and after the administration of the reading comprehension test in favor of the post one.
The greater mean score of the experimental group's posttest implies thatthe experimental group students' level in overall reading comprehension was improved due to using the audiobook. This increase indicates the effect of this program.

\section{Testing the second hypothesis:}

The second hypothesis stated that there is a significant difference at 0.05 level between the mean score of the control group and the experimental group on the post administration of the reading 
comprehension test in favor of the experimental group.

In order to validate this hypothesis, the researcher used ttest that is presented in the following table:

Table (3)

$T$ - test of the control and experimental groups on the post administration of the EFL reading comprehension test

\begin{tabular}{|c|c|c|c|c|c|c|c|c|}
\hline $\begin{array}{l}\text { Main } \\
\text { Skills } \\
\end{array}$ & $\begin{array}{c}\text { Sub } \\
\text { Skills } \\
\end{array}$ & group & $\mathrm{N}$ & Mean & $\begin{array}{c}\text { Std. } \\
\text { Deviation } \\
\end{array}$ & df & $\mathrm{t}$ & Sig \\
\hline \multirow{4}{*}{ Skimming } & \multirow{2}{*}{ first skill } & experimental group & 30 & 2.21 & 0.538 & \multirow{2}{*}{58} & \multirow{2}{*}{5.052} & \multirow{2}{*}{0.01} \\
\hline & & control group & 30 & 1.29 & 0.836 & & & \\
\hline & \multirow{2}{*}{$\begin{array}{l}\text { Second } \\
\text { skill }\end{array}$} & experimental group & 30 & 2.29 & 0.474 & \multirow{2}{*}{58} & \multirow{2}{*}{11.242} & \multirow{2}{*}{0.01} \\
\hline & & control group & 30 & 0.67 & 0.634 & & & \\
\hline \multirow{8}{*}{ Scanning } & \multirow{2}{*}{$\begin{array}{l}\text { Third } \\
\text { skill }\end{array}$} & experimental group & 30 & 2.46 & 0.228 & \multirow{2}{*}{58} & \multirow{2}{*}{10.536} & \multirow{2}{*}{0.01} \\
\hline & & control group & 30 & 0.79 & 0.836 & & & \\
\hline & \multirow{2}{*}{$\begin{array}{l}\text { Fourth } \\
\text { skill }\end{array}$} & experimental group & 30 & 2.33 & 0.432 & \multirow{2}{*}{58} & \multirow{2}{*}{9.415} & \multirow{2}{*}{0.01} \\
\hline & & control group & 30 & 0.83 & 0.758 & & & \\
\hline & \multirow{2}{*}{ Fifth skill } & experimental group & 30 & 2.38 & 0.381 & \multirow{2}{*}{58} & \multirow{2}{*}{11.322} & \multirow{2}{*}{0.01} \\
\hline & & control group & 30 & 0.71 & 0.710 & & & \\
\hline & \multirow{2}{*}{ sixth skill } & experimental group & 30 & 2.38 & 0.381 & \multirow{2}{*}{58} & \multirow{2}{*}{13.259} & \multirow{2}{*}{0.01} \\
\hline & & control group & 30 & 0.58 & 0.634 & & & \\
\hline \multirow{2}{*}{$\begin{array}{l}\text { Critical } \\
\text { reading }\end{array}$} & \multirow{2}{*}{$\begin{array}{l}\text { seventh } \\
\text { skill }\end{array}$} & experimental group & 30 & 2.42 & 0.317 & \multirow{2}{*}{58} & \multirow{2}{*}{11.822} & \multirow{2}{*}{0.01} \\
\hline & & control group & 30 & 0.75 & 0.704 & & & \\
\hline \multirow{2}{*}{$\begin{array}{l}\text { Critical } \\
\text { reading }\end{array}$} & \multirow{2}{*}{$\begin{array}{l}\text { Eighth } \\
\text { skill }\end{array}$} & experimental group & 30 & 2.38 & 0.381 & \multirow{2}{*}{58} & \multirow{2}{*}{11.798} & 0.01 \\
\hline & & control group & 30 & 0.88 & 0.583 & & & \\
\hline & & experimental group & 30 & 18.83 & 1.181 & 58 & 35.120 & 001 \\
\hline Hed & 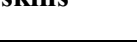 & control group & 30 & 6.50 & 1.519 & 80 & 50.120 & 0.01 \\
\hline
\end{tabular}

Thus, the experimental group students' exceeded their mates of the control group who studied through the regular activities planned by the Ministry of Education.

\section{The Effect size of the proposed activities:}

First, eta square $\left(\eta^{2}\right)$ was estimated to calculate the effect
Results in table (3) showed that there was a statistically significant difference between the mean score of the control and experimental groups students' at (0.01) level in the post administration of the reading comprehension test in favor of the experimental one. These differences were due to using the proposed audiobook activities. 
The following table illustrates the effect size of using audiobook on the experimental group students' reading comprehension skills. size of the proposed audiobook activities on the students'reading comprehension skills. Eta square ( $\eta 2)$ was estimated after calculating the $\mathrm{t}$-value. Theformula was: $\eta 2=\frac{\mathrm{t} 2}{\mathrm{t} 2+\mathrm{df}}$

Table (4)

Value of ( $\eta 2)$ and the Level of Effect Size

\begin{tabular}{|c|c|c|c|c|c|c|c|c|}
\hline $\begin{array}{c}\text { The } \\
\text { Independen } \\
\text { t Variable }\end{array}$ & $\begin{array}{r}\text { The } \\
\mathrm{V} \\
\mathrm{R} \\
\text { Compre } \\
\end{array}$ & $\begin{array}{l}\text { pendent } \\
\text { iable } \\
\text { ding } \\
\text { nsion Skills } \\
\end{array}$ & $\mathbf{t}$ & $\mathbf{t}^{2}$ & $t^{2}+d f$ & $\eta^{2}$ & $\begin{array}{c}\text { The } \\
\text { Effect } \\
\text { Size }\end{array}$ & $\begin{array}{l}\text { The } \\
\text { Effect }\end{array}$ \\
\hline \multirow{9}{*}{ Audio book } & \multirow{2}{*}{$\begin{array}{c}\text { Skimmin } \\
\mathrm{g}\end{array}$} & first skill & 5.052 & 25.52 & 83.52 & 0.31 & $31 \%$ & high \\
\hline & & Second skill & 11.242 & 126.38 & 184.38 & 0.69 & $69 \%$ & high \\
\hline & \multirow{4}{*}{ Scanning } & Third skill & 10.536 & 111.01 & 169.01 & 0.66 & $66 \%$ & high \\
\hline & & Fourth skill & 9.415 & 88.64 & 146.64 & 0.60 & $60 \%$ & high \\
\hline & & Fifth skill & 11.322 & 128.19 & 186.19 & 0.69 & $69 \%$ & high \\
\hline & & sixth skill & 13.259 & 175.80 & 233.80 & 0.75 & $75 \%$ & high \\
\hline & \multirow{2}{*}{$\begin{array}{l}\text { Critical } \\
\text { reading }\end{array}$} & $\begin{array}{c}\text { seventh } \\
\text { skill }\end{array}$ & 11.822 & 139.76 & 197.76 & 0.71 & $71 \%$ & high \\
\hline & & Eighth skill & 11.798 & 139.19 & 197.19 & 0.71 & $71 \%$ & high \\
\hline & \multicolumn{2}{|c|}{ Total skills } & 35.120 & 1233.41 & 1291.41 & 0.96 & $96 \%$ & high \\
\hline
\end{tabular}

Results in table(4) illustrate the eta square for each reading comprehension skills. The effect size values are $(0.31,0.69,0.66$, $0.60,0.69,0.75,0.71$ and 0.71 respectively). It is obvious that all of these values exceeded (0.71) which reflects a high effect size for all the target reading comprehension skills.

The effect size ranged between (0.31and 0.75) for the target reading comprehension skills which points to the high impact of the experimental treatment in this study. Thus, it can be assumed that audiobook activities improved Jordanian basic education Students' reading comprehension significantly.

To sum up, all the values of eta square ( $\eta 2)$ mentioned in table(4) are higher which show the great effect of audiobooks activities on improving Jordanian basic education Students' reading comprehension . 


\section{Discussion of Results:}

According to the tables presented above, the present study reached the

following results:

1. There is a significant difference at 0.05 level between the mean score of the experimental group students on the pre - post administration of the reading comprehension test in favor of the post one.

2. There is a significant difference at 0.05 level between the mean score of the control group and the experimental group on the post administration of the reading comprehension test in favor of the experimental group.

These results are congruent with the results of the previous studies in the field of EFLsuch as Shadi (2015) who investigated the effectiveness of usingWebQuests on first year secondary school students' English reading comprehenstion skills and writing and El Dwil (2017) who examined the effect of digital stories for developingreading comprehension skills of (35) EFL preparatory school pupils. The study results are congruent with the previous studies that investigated audiobook and reading comprehension skill such as Karatal (2011) who revealed that audiobooks are helpful for improving reading comprehension and listening skills as well as reading fluency.The results of this study are also in agreement with Turker (2010) who showed, in a comparative study, that there is a positive effect on the ability of EFL university students to comprehened a selected text and intermediate level students gained more benefit from using audiobook than the elementary level. The findings of this study are also congruent with Monntgomry (2009) who found that audiobooks can improve reading comprehension and academic performance for both English learners and for native English speakers especially at the middle school level. There's also congruenc with Whittingham and et.al (2013) who indicated that struggling readers' use of audiobooks had a positive impact on reading skills and attitudes toward reading.

The present study revealed that the effect size of audiobook program on students' reading comprehension skill was large as the students of the experimental group outperformed those of the control group on post application. These results are congruent with literature findings (Karatal,2011; Turker,2010 and Monntgomry, 2009), which implied that traditional learning environments 
do not prepare students for the high degree of performance.

Based on the experiment and its findings,audiobook activities enhanced students' reading comprehension skills in terms that they integrated new concepts or information into their established knowledge structures (schema). The proposed program also used integrated language learning in terms that students had to listen, then read.In addition, audiobook engaged learners' interest,encouraged critical thinking and supported cooperative learning.

These positive findings and significant differences between the control and experimental group might be due to the efficiency of the audiobook program. The design of this program had certain features that helped the experimental group do well on the post application of the pre posttests of reading comprehension. First, using peer-learning helps learners to correct each other's mistakes by exchanging their own information. Second, using the audiobook as a teaching technique for the first time in Jordan to teach reading comprehenion skills was a big challenge for the researcher. Finally, using the audiobook made students depend on themselves and cooperate together in addition to being aware of what they should do during their learning.

\section{Conclusion}

This study concluded that using audiobooks activities can improve Jordanian basic education students' reading comprehension.

\section{Recommendations}

Based on the previous results, the present study recommends the following:

1. Examining the effectiveness of audioboks on EFL classes to improve EFL other language skills such as speaking or listening.

2. Examining the effect of audiobook on EFL learners' motivation towards other language skills such as speaking and listening.

3. Further researches should be conducted to determine the effectiveness of audiobook on other school levels.

\section{Suggestions for Further Research}

The following suggestions can be considered for further research:

1. Investigating the effectiveness of audiobooks in EFL classes to improve EFL other language skills such as speaking or listening.

2. Further research should be conducted to determine the 
effectiveness of audiobook on other school levels.

\section{References}

Al Dwil, F. (2017). Using digital stories for developing reading skills of EFL preparatory school pupils. Unpublished M. A. Thesis, Damietta University, Egypt.

Allen, S. (2003). An analytic comparison of three models of reading strategy instruction. IRAL, 41, 319338.

Beck, I., \& McKeown, M. (2006). Improving comprehension with questioning the author. New York, NY: Scholastic.

Burkey, M. (2013). Audiobooks for youth: a practical guide to sound literature. American Library Association.

Burkey, M. (2013). Voices in my head: Audiobooks and common core. American Library Association.

Cahill, M. \& Moore, J. (2017). A sound history Audiobooks are music to children's ears. Spring, Children and Libraries

Camlot, J. (2003). Early talking books: Spoken recordings and recitation anthologies, 1880-1920. Book History. 6: 147-173.Cardillo
Cervetti, G. N., \& Hiebert, E. H. (2015). The sixth pillar of reading instruction: Knowledge development. The Reading Teacher, 68 (7), 548-551.

Costea, O. (2011). Reading models and approaches in school. Euro Mentor Journal, 2 (4) DECEMBER2011

El-Kahlout, Y. (2010). The effectiveness of using guided discovery on developing reading comprehension skills for the eleventh graders in Gaza Governorates. AlAzher University, Gaza.

Erben, T., Ban,R., \& Castanda, M. (2009). Teaching English language learners through technology. Routledge. Taylor and Franciss Group, New York, NY.

Freahat, N., \& Al-Faoury, O. (2015). Reading Passages and skills in Jordanian high school and university EFL textbooks: A comparative analytical study. Theory and Practice in Language Studies, 5 (1), pp. 16-27, July 2019 http

Haboush, Z. Y. (2010). The effectiveness of using a Program Based on Multiple Intelligences Theory on Eighth Graders' English Reading Comprehension 
Skills. MA. Thesis. Islamic University of Gaza Available on elibrary.iugaza.edu.ps.

Hamilton, S. \& Glasoe, F. (2006). Evaluation of Children with Reading Difficulties. American Family Physician. 74, (12), 15-25.

Hashemi, A., Mobini, F., \& Karimkhanlooie, G. (2016). The impact of content-based Pre-reading Activities on Iranian High School EFL Learners' Reading Comprehension. Journal of Language Teaching and Research, 7 (1), 137-145, July 2019 DOI: http://dx.doi.org/10.17507/jlt r.0701.15

Hett, K. (2012). Technologysupported Literacy in the Classroom: Using Audiobooks and Digital storytelling to Enhance Literacy instruction. Illinois Reading Council Journal, 40 (3), 30-36.

Kartal, G. (2011). The Use of Audiobooks in EFL class for improving reading and listening skills. 2 nd International Conference on New Trends in Education and Their Implications 27-29 April, 2011, Kony, AntalyaTurkey.
Kelly, G. (2007). Deeper reading. Portland Maine: Stonehouse, USA.

Liu, Z. (2005). Reading behavior in the digital environment changes in reading behavior over the past ten years. The Journal of Documentation, 61 (6), 700-712.

Mart, T. (2012). Developing speaking skills through reading. International Journal of English Linguistics, 2 (6), 220-233.

Milano, A., Lorusso, L., \& Molteni, M. (2009). The effects of Audiobooks on the psychosocial adjustment of pre-adolescents and adolescents with dyslexia. Published online 1 September 2009 in Wiley Interscience. John Wiley \& sons, Ltd. Dyslexia 16: 87-97 (2010). 22

Montgomery, J. (2009). Using Audiobooks to improve reading and academic performance.

www.ericdocumentreproduct ionservice, ED.NO.505947.Retrivedfrom http//files.eric.ed.gov/fulltext /ED505947.pdf.

Nunan, D. (2003): The impact of English as a global language on educational policies and practices in the Asia - Pacific 
Region. TESOL quarterly, 37(4), 589-613.

Serafini, F. (2004). Audiobooks \& literacy: An educator's guide to utilizing Audiobooks in the classroom. New York: Listening Library

Shadi, E.H. (2015). The effectiveness of Web Quest program in developing school students' English reading and writing skills. Unpublished Ph.D thesis, Ain Shams University, Egypt.

Tashtoush, H., \& Smadi, O. (2008). Reading comprehension and strategies used by Jordanian EFL Secondary stage students in four text type situations (Doctoral dissertation).

Turker, S. (2010). The effectiveness of using Audiobooks on the reading comprehension of selected text by University EFL students at different Proficiency Levels. (Master Dissertation, Bilkent University, Ankara, Turkey, and Retrieved from: www.thesis.bilkent,edu.tr.pdf Varley, P. (2002). As Good as Reading? Kids and the
Audiobook Revolution. Horn Book Magazine, 78 (3), 25162.

Whittingham, J. (2013). Use of Audiobooks in a school library and positive effects of struggling readers' participation in a librarysponsored Audiobook club. School Library Research.Journal of the American Association of School Librarians. 16.

Wolfson, G. (2008). Using Audiobook to Meet the Needs of Adolescent Readers.American Secondary Education 36 (2) SPRING. World Economic 23 Forum Website, Available on: http://www.weforum.org/pdf/ AnnualReport. Retrieved on September 5,2017.

Young, C. (2016). Audiobooks Are having A moment. Profound News. 38 (10). http://www.prosoundnetwork .com.

Zainal, Z., Husin, S. H. B. M., \& Pendidikan, F. (2011). A study on the effects of reading on writing performance among faculty of civil engineerin 